\title{
Engineering the Empire: British Water Supply Systems and Colonial Societies, 1850-1900
}

\author{
John Broich
}

A

s a revolution in urban governance swept Britain from the 1840s onward, a revolution in water supply and drainage infrastructure followed. gravitation scheme that reforming municipalities aspired to build. It entailed drastically reshaping landscapes in the hinterlands of cities by damming rivers, raising lakes, or flooding valleys and then piping water under pressure to sometimes distant cities; it also, promoters hoped, would reform urban environments and societies at the same time. Between 1840 and the end of the century, engineers in Britain executed it approximately one hundred times, but the gravitation scheme had a life beyond the bounds of Britain. In the second half of the nineteenth century, engineers - usually the very same individuals who had carried them out in Britainintroduced the scheme to cities such as Bombay, Colombo, Hong Kong, and Singapore. There, the gravitation scheme also had a transformative influence; it was a project of environmental and technical change that helped to solidify the modernizing colonial state.

This water system was a practical solution to the challenge of providing growing urban populations in Britain with water, but it represented more than that to the advocates of improvement in cities such as Bradford, Glasgow, and Manchester. For them, the design was ideally suited to accomplish goals that combined physical and moral amelioration. In their eyes, it was the best technology for keeping cities flush with water for drinking and bearing away human and industrial poisons, and because it was presumed to be the best method for introducing water to all homes in all corners of the city, they believed that it was the best way to induce working-

John Broich is a visiting assistant professor of history at Amherst College. The author is grateful to participants and attendees of the Foreign Expertise and Environmental Change in Nineteenth- and Twentieth-Century Asia panel at the 2006 meeting of the American Historical Association for their constructive criticisms. He would like to thank Paul Seaver, Peter Stansky, and Richard White. He would also like to thank John, Mary, and Anne Ursu. Finally, he would like to express his gratitude to the JBS's anonymous reviewers.

Journal of British Studies 46 (April 2007): 346-365

(C) 2007 by The North American Conference on British Studies.

All rights reserved. 0021-9371/2007/4602-0005\$10.00 
class families - who they imagined were averse to water use - to use it for drinking (as an alternative to alcohol) and for eliminating demoralizing grime. In other words, only if the poor would adopt more water usage could the warrens of the cities be rid of environmental and moral filth. In the empire, those who promoted the gravitation scheme were guided by much the same motivations, but there, the targets of water reform were chiefly identified by race rather than class.

Confident that they were spreading enlightenment and civilization, colonial officials and engineers sought to impose this technological-environmental system on the landscapes of the empire. These efforts had long-standing consequences for both environmental and social regimes. On the subcontinent, and in Sri Lanka, Japan, and China, engineers diverted rivers, created lakes, drowned villages, and dislodged farmers in order to provide sometimes distant cities with water. The projects linked this environmental change in the hinterlands to social change in the cities. The new colonial water supplies often replaced traditional water systems; where control over water sources was formerly decentralized, water systems became more and more centralized. "Official" water sources proliferated, along with official instruction to use them. ${ }^{1}$

Historians and political theorists argue that reforming the conditions of urban life was an important unwritten strategy of the "improvers" of liberal Victorian Britain and its empire, in order to eliminate dangers and impediments from the burgeoning city and to enable townspeople to experience "modern" life. In The Rule of Freedom Patrick Joyce develops Foucauldian ideas in examining how British leaders ordered social life by ordering the Victorian city. By lighting the city, making it easy to move about the city, and thereby making it easy to comprehend the city, successful rule, he argues, was achieved by taking steps to enable urban subjects to lead the sort of life that realized modern society and reinforced the state. Citing "the agency of running water," Joyce suggests, in a tantalizingly brief treatment, that water supply and sewerage systems in Britain steered behavior, introduced new standards of normalcy in everyday life, and individuated subjects by creating what Joyce calls the "hygienic self." Again, intervention was not on its face coercive; he writes, "Liberalism [was] a variant of governmentality which sought to secure interventions in conduct which were neither arbitrary nor direct." ${ }^{3}$ David Scott extends similar ideas on liberalism as a strategy of power to the empire. For Scott, the colonial state proceeded by eliminating or rearranging existing conditions that, in the eyes of imperial authorities, held native society in a nonmodern or "unimproved" state. The task of the modernizing governor was to reformulate conditions "to oblige subjects to transform themselves in a certain, that is $\mathrm{im}$ proving direction." "The case of the gravitation scheme, undertaken in both Glasgow and Hong Kong, reveals that the creation of urban systems as a strategy of

\footnotetext{
${ }^{1}$ Christopher Hamlin has shown that, at the beginning of the sanitary and water reform movement, sanitarians such as Edwin Chadwick fought and won contests to determine how "improvement" was to be defined and achieved; that is, it was decided to treat the side effects of poverty, poisonous byproducts that threatened the British workforce and threatened to expand into middle-class circles, instead of the root causes of poverty and disease. Christopher Hamlin, Public Health and Social Justice in an Age of Chadwick, Britain, 1800-1854 (Cambridge, 1998).

${ }^{2}$ Patrick Joyce, The Rule of Freedom: Liberalism and the Modern City (London, 2003), 70-75.

${ }^{3}$ Ibid., 70 .

${ }^{4}$ David Scott, "Colonial Governmentality," Social Text 43 (Autumn 1995): 200.
} 
modern governance was reproduced; tactics of state power were not always distinct in Britain and the empire. ${ }^{5}$

Social and environmental conditions in both places certainly were distinct, but the engineers who undertook the gravitation scheme in the empire betrayed a failure to appreciate these differences. They approached the task of lifting the gravitation scheme from the landscapes of Britain and superimposing it on the empire with great confidence-and largely unmodified designs and procedures. But that confidence was sorely tested in the face of multiple fronts of resistance. The difficulties of such attempts at straightforward imposition have been the focus of much recent work by historians of science, technology, and empire. ${ }^{6}$ In Science, Technology, and Medicine in Colonial India, David Arnold describes the difficulty of transferring technologies from metropole to empire without emendation. ${ }^{7}$ Arnold and other historians argue that technology transfer was tempered by British political and administrative exigencies and economic strategies that sometimes favored limits on proliferation, but more important, technology transfer was complicated by Indian observers who did not share British engineers' and politicians' faith in its advantages. ${ }^{8}$ Arnold and Mark Harrison describe the resistance and constraints offered by Indian society to British public health measures, while others have described social and cultural checks on the introduction of British agricultural, irrigation, rail, and scientific forestry initiatives. ${ }^{9}$ Resistance was based on a complex of related motivations, from a resentment of adopting technologies or techniques that clearly benefited British officials or capitalists to an aversion to funding projects or programs through taxes, to anger over disruptions to local land use or other traditions, and to straightforward doubt about the new technologies' efficacy. Similarly, local inhabitants resisted the water projects from Karachi to Colombo and beyond because they resented paying for a project initiated by the British, because they doubted the project's necessity, and indeed for all the justifications highlighted by Arnold and Harrison. The gravitation scheme inspired resistance for another reason that appears more rarely in the literature: religion. Townspeople in at least two Indian cities resisted the creation of water schemes because they would interfere with traditional worship practices.

${ }^{5}$ Joyce draws analogies between certain expressions of metropolitan and colonial governmentality but, presumably because of a lack of case studies, fails to recognize the water infrastructure of the colonial city as the domain of governmentaility, just as it was in Britain. Joyce, Rule of Freedom, 253-57.

${ }^{6}$ This work has turned away from an earlier tendency to simply describe how technologies were thrust upon colonial societies as tools of empire. See, e.g., Daniel R. Headrick, The Tools of Empire: Technology and European Imperialism in the Nineteenth Century (Oxford, 1981).

${ }^{7}$ David Arnold, Science, Technology, and Medicine in Colonial India, 1760-1947 (Cambridge, 2000), 92.

${ }^{8}$ Ibid., 92-93; Mark Harrison, Public Health in British India: Anglo-Indian Preventive Medicine, 1859-1914 (Cambridge, 1994), 99-116, and elsewhere; R. J. Henry, "Technology Transfer and Its Constraints: Early Warnings from Agricultural Development in Colonial India," in Technology and the Raj: Western Technology and Technical Transfers to India, 1700-1947, ed. Roy Macleod and Deepak Kumar (London, 1995), 51-77.

${ }^{9}$ David Arnold, Colonizing the Body: State Medicine and Epidemic Disease in Nineteenth-Century India (Berkeley, 1993), 17-18, 238; Ravi Ahuja, “'The Bridge Builders': Some Notes on Railways, Pilgrimage, and the British 'Civilizing Mission' in Colonial India," in Colonialism as Civilising Mission: Cultural Ideology in British India, ed. Harald Fischer-Tiné and Michael Mann (London, 2004), 106-8; Madhav Gadgil and Ramachandra Guha, "State Forestry and Social Conflict in British India," in Peasant Resistance in India, 1858-1914, ed. David Hardiman (Delhi, 1992), 258-95. 
More important, this case presents an example of an obstacle that the literature on science and technology transfer does not deal with sufficiently-the environment itself. ${ }^{10}$ Soil conditions, earthquakes, and especially the tropical climate provided the most serious barriers to water supply engineers. Designs drafted in London and materials tested in the Lake District performed differently, and sometimes disastrously, in the hills of Sri Lanka or mud of Singapore. Since the gravitation schemes described here were undertaken not by elected municipal bodies but rather by provincial governments or Crown agents in London, the obstructions of the landscape proved more challenging than those of defiant townspeople. ${ }^{11}$ The theme of environmental resistance has been well developed in the environmental histories analyzing the projects of modernizing states, whether looking at failed attempts at acclimatizing commercial species to various parts of the globe or systems of flood control. ${ }^{12}$ Although the modernizing central state brought capital and political will to projects of environmental changes, the landscapes it encountered never reacted like the blank canvases on which experts had drawn their designs. The case of the gravitation scheme, then, provides an opportunity to draw on the environmentcentered picture of friction offered by environmental historians and the socially oriented depiction of resistance offered by historians of science and technology.

Despite the difficulties of environmental resistance and social antipathy, engineers succeeded in negotiating the gravitation scheme into new social and physical terrains. The gravitation scheme was the boldest rendering of reformers' dreams of a physically and morally healthy, productive, modern populace. In both Britain and the empire, moral governance was translated into water governance through the same technology. Through rearranging the environment, through guiding the behavior of water, the modernizing state found new ways to guide certain behavior, even in the individual household, without any apparent direct intervention. The obvious point of intervention was in the hinterland, where landscapes and communities were violently overturned by gravitation schemes; in cities, the ordering of society through water-and the reification of state power-was, and has largely remained, out of sight.

\section{THE GRAVITATION SCHEME: A TECHNICAL, SOCIAL, AND MORAL FIX}

This model water system ultimately came into being because the growing industrial towns of midcentury Britain had water problems. Their concentrated populations

\footnotetext{
${ }^{10}$ Exceptions include some studies on British India's canal systems as led by Elizabeth Whitcombe's important work in which she describes the waterlogging, salinization, and epidemiological consequences of the projects and Timothy Mitchell's examination of the High Aswan Dam's epidemiological and social backfire. See Elizabeth Whitcombe, Agrarian Conditions in Northern India: The United Provinces under British Rule, 1860-1900 (Berkeley, 1972); Timothy Mitchell, Rule of Experts: Egypt, Technopolitics, Modernity (Berkeley, 2002); Rohan D'Souza surveys the literature on British water systems on the subcontinent in "Water in British India: The Making of a Colonial Hydrology," History Compass 4 (2006): 621-28.

${ }^{11}$ Although, Harrison notes that public health initiatives were restrained by the fear of inciting civil unrest; Harrison, Public Health in British India, 116.

${ }^{12}$ See, for only a few examples, Donald Worster, Dust Bowl (New York, 1979); Warren Dean, Brazil and the Struggle for Rubber: A Study in Environmental History (Cambridge, 1987); Jared Orsi, Hazardous Metropolis: Flooding and Urban Ecology in Los Angeles (Berkeley, 2004).
} 
generated large volumes of waste in very cramped quarters, which made it difficult and sometimes impossible to remove waste from proximity to habitations and local water sources at the very moment when increasing populations demanded larger and larger volumes of water free from human and industrial poisons.

At the same time, sanitary experts preached that fresh water must be supplied throughout towns, made available within the living quarters of townspeople of all classes at all times, and that water, once dirtied by use, must be drained away immediately. A prominent disease theory of the time stated that epidemic bred in environments with stagnant, dirty water; such places emanated a sort of diseaseinducing cloud-a "miasma." Sanitarians such as the renowned Edwin Chadwick and a series of official inquiries stated that public health depended on moving water through the urban body at large and thus eliminating miasmas.

The state, embodied by parliamentary committees and royal commissioners, found its citizens unwilling or unable to safeguard its interests. Cholera struck the country in 1831; typhus, in 1837: the government's registrar general showed alarming rates of mortality in Britain's cities. ${ }^{13}$ The unwatered, unwashed cities threatened to unravel, or at least disastrously foul, the social fabric. The solution, in the words of the 1844-45 commission, was to "promote habits of cleanliness among the population," but it complained that authorities could not compel the working class to use more water unless it was "readily accessible at all times, without trouble." ${ }^{14}$ Only with universal, affordable water service could city dwellers and landlords be required by law to connect their properties to water supplies. Only if the state better managed natural resources could it better manage the behavior of its people and ultimately preserve itself. ${ }^{15}$

Water reformers were also spurred by an ethical rationale. In reformers' eyes, cramped, unflushed environments harbored moral disease as well as miasmas. Philanthropists and sanitarians such as Edwin Chadwick saw that the poor were unwilling or unable to obtain water from a distance if it was not piped into their habitations, and reformers knew that, even when landlords had laid on a water supply to their properties, most water companies did not provide water under sufficient pressure to reach the upper floors of poor tenements. Sanitary officials and philanthropic campaigners believed that working-class people gave in to hopelessness and spiritual corruption if they had insufficient access to clean water and could not clean their habitations and bodies. In 1850, the Edinburgh Review stated, "There is a most fatal and certain connexion between physical uncleanliness and moral pollution: the condition of the population becomes invariably assimilated to that of their habitation." ${ }^{16}$ Many reformers closely linked impure water supplies to the abuse of alcohol. Reverend John Garwood of the London City Mission wrote in 1859, "The universal testimony of our Missionaries is, that . . . a very large amount of drunkenness is occasioned by the great difficulty of obtaining

\footnotetext{
${ }^{13}$ Second Report of the Commissioners for Inquiring into the State of Large Towns and Populous Districts, Parliamentary Papers, vol. 18 (London, 1845), 2.

${ }^{14}$ Ibid., 50.

${ }^{15}$ For an important work on Chadwick and his assumptions about disease and society, see Hamlin, Public Health and Social Justice.

${ }^{16}$ W. O'Brien, "Supply of Water to the Metropolis," Edinburgh Review 91 (April 1850): 384.
} 
pure water to drink in many of the poor parts of London."17 The poor would then drag themselves and their families down into despair and cease to be useful, productive members of society. A writer in Dickens's weekly journal, Household Words, anticipated that once there was "a constant supply of water at high pressure within reach of every housewife's thumb . . . we shall have advanced also in the moral and mental discipline of urban life to a better state." ${ }^{\prime 18}$

From the late $1840 \mathrm{~s}$, Britain witnessed a "water reformation," as town councils, motivated by these public health and social reform concerns, replaced old water companies - and nearly all towns were supplied by commercial enterprises at the time. Town councils usually undertook new works construction very soon after purchasing, or "municipalizing," their water companies, as councils searched for larger, cleaner water sources. Of the roughly 180 towns and cities that municipalized existing enterprises or inaugurated new water utilities from around 1840 until the end of the century, the majority secured new water sources and built new works within a only few years of eliminating old companies. ${ }^{19}$ These water projects, along with other efforts to deal with the problems of growing towns, demanded the significant expansion in the rights and responsibilities of town councils across England and Wales. ${ }^{20}$ The councils had to receive legal authority from Parliament to purchase companies or to offer new water supplies, to buy land, to secure water sources, and to raise funds to finance all of these. Most often, town councils financed water reform by selling municipal stock and using water rates to service the amassed debt.

At the same time local governments acquired the authority and means of transforming their cities, the gravitation scheme was becoming the preeminent water supply technology. Slowly emerging in the 1820s and 1830s, this began as a simple adaptation of the mill reservoir. ${ }^{21}$ For centuries, mill owners had impounded water for the purpose of using falling water to turn wheels for textile or other manufacturing; they dammed rivers or embanked and raised ponds that were situated at an elevation above their mills and then sent water rushing down a channel that passed through or beside their works. In the first decades of the nineteenth century, a few mill owners began selling surplus water to local manufacturing communities

\footnotetext{
${ }^{17}$ John Garwood, quoted in W. Archdall O'Dougherty, Water for Domestic Use: Evils Attending the Use of Impure Water, to Health, to Purse, and to Morals (n.p., 1862), 21. This source quotes many reformers on what they viewed as the close connection between poor water quality and alcohol abuse among the poor. Also, Edwin Chadwick linked insufficient water to the dirty state of the masses and their quarters and the dirty state of his or her quarters to the disgrace of the working-class individual and that disgrace to the predilection to drink. He reported in 1842 that the "undrained" abode "has an effect on the moral habits by acting as a strong and often irresistible provocative to the use of fermented liquors." Edwin Chadwick, Report on the Sanitary Condition of the Labouring Population of Great Britain (1842; repr., Edinburgh, 1965), 196-97.

${ }^{18}$ John Morely, "Piping Days," Household Words 10 (14 October 1854): 197-98.

${ }^{19}$ Arthur Silverstone, The Purchase of Gas and Water Works: With the Latest Statistics of Municipal Gas and Water Supply (London, 1881), 88-125.

${ }^{20}$ The 1835 Municipal Corporations Act eliminated all existing corporations-the city of London's local government excluded-and created town councils in their places. These new councils had relatively few responsibilities specified at first. See Derek Fraser, "Introduction: Municipal Reform in Historical Perspective," in his Municipal Reform and the Industrial City (New York, 1982), 1-6, and Power and Authority in the Victorian City (New York, 1979), 164.

${ }^{21}$ Peter Ellerton Russell, "John Frederic La Trobe-Bateman, FRS, Water Engineer, 1810-1889" (master's thesis, University of Manchester, 1980), 59-60.
} 


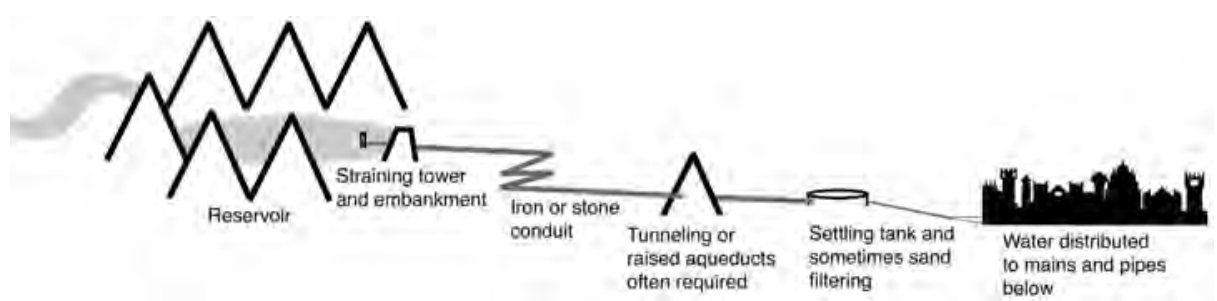

Figure 1-A schematic of the gravitation scheme (figure by John Broich).

for domestic use. The practice expanded along with the growth of towns. By 1835, there were a dozen reservoirs that served, at least partially, to provide a town with water. ${ }^{22}$ From the 1840 s, the scale and number of the projects increased as municipal officials and sanitary experts saw the potential for the gravitation scheme to solve the practical problems of urban water supply and to achieve their social goals.

The system required a superabundant source of water such as a river, a lake, a group of streams, a number of springs, or a combination of these. The greater the volume of water to be collected, the more likely the project would prove sufficient to meet the future wants of the city and support the expansion of the population, and the city's industrial productivity, for generations to come. Because the gravitation scheme drew on water sources in the city's hinterland, well away from settlements, it appealed to sanitarians and engineers who thought water sources near to cities were liable to become contaminated and sometimes had proven insufficient to the wants of the city. Then, the method required that this water be accumulated and reserved, perhaps by diverting streams into an artificial reservoir, embanking a lake to hold additional water, or enclosing a valley through which a river passed at one end. The reservoir had to be built at an elevation above the city. An aqueduct or iron pipeline delivered the new water supply to the city in need - whether ten miles away or one hundred - and because the water arrived from a height, no pumping was required to convey it over a distance (it was because of this feature that the schemes were called "gravitation schemes"). The engineering and sanitary consensus held that all towns' water supplies should be delivered under high pressure without the aid of expensive steam pumping. The poor could not be compelled to reform their water habits until the water was actually universally available throughout the city, and this constant high pressure would make that so (see fig. 1).

The gravitation system came to predominate over alternatives such as well fields, schemes for filtering river water, and schemes involving pumping, in part because a coterie of influential engineers promoted it to town officials throughout Britain. Thomas Hawkesley, a member of the Royal Commission on the Health of Towns and one of Britain's most celebrated water engineers, built gravitation systems for Leicester and Rochdale; James Simpson, vice president of the Institution for Civil Engineering, designed schemes for Aberdeen and Liverpool; chief engineering inspector of Parliament's Local Government Board, Robert Rawlinson, promoted

${ }^{22}$ Ibid., 25, 59-60. 
a gravitation scheme (never built) for London. ${ }^{23}$ But the engineer who led the way in transforming the schemes from small millponds to monumental projects, and who constructed by far the most of these schemes (around fifty), was John Frederic La Trobe Bateman (1810-89).$^{24}$ Edwin Chadwick himself wrote Bateman in 1844, imploring him to become a specialist in the process. ${ }^{25}$ From the $1840 \mathrm{~s}$ through the next several decades, he submitted several gravitation schemes per year to local authorities throughout Britain. ${ }^{26}$ His greatest projects, the Longendale and Thirlmere reservoirs for Manchester and his Loch Katrine system for Glasgow, manufactured some of the largest lakes in Britain and represented some of the most considerable public expenditures of any kind of their age. Glasgow spent 1 million pounds on creating a reservoir nine miles long and one mile wide at its widest. ${ }^{27}$ Though it was more expensive to create than traditional well schemes, the gravitation scheme multiplied because engineers found it effective; it satisfied social goals, satisfied orthodox sanitary principles, and therefore became dogma among the engineering and sanitarian establishment. ${ }^{28}$ In the empire, these same engineers demonstrated their belief in the universality of these engineering and social principles.

\section{EXPORTING A DESIGN FOR ENVIRONMENTAL TRANSFORMATION}

The gravitation scheme spread to the cities of the empire because colonial officials mimicked Britain's state-of-the-art engineering. Bombay's chief engineer, Henry

${ }^{23}$ Leicester, Rochdale, and other towns built Hawkesley gravitation schemes; see Scott Edward Roney, "Trial and Error in the Pursuit of Public Health: Leicester, 1849-1891" (PhD diss., University of Tennessee, Knoxville, 2002), 80; Leicester Water Undertaking, 1847-1874 (Leicester, 1974), 59; and Rebe Taylor, Rochdale Retrospect (Rochdale, 1955), 127-28. Simpson promoted the system for Aberdeen and Liverpool; see James Simpson, Report on the Most Efficient Means of Obtaining an Increased Supply of Water to the City of Aberdeen (Aberdeen, 1855), 11; James Simpson and James Newlands, Liverpool Water Supply (Liverpool, 1849), 10, 34, 48-50. For Rawlinson, see The Times, 2 June 1898, 6.

${ }^{24}$ It is difficult to ascertain the exact number of his gravitation systems. Even his only biographer can offer only a range of the number of reservoirs he completed, seventy to eighty, and some of those were not for drinking water. Bateman also promoted some schemes that were adopted by town councils but never completed. I derive my figure of fifty from Russell, "John Frederic La Trobe-Bateman," 176, 182, 199-200, 211, 263; and J. F. Bateman, "On a Constant Water Supply for London: A Paper read at a Meeting of the Health Department of the National Association for the Promotion of Social Science" (n.p., 1867; in the possession of the Institution for Civil Engineering, London), 1. Geoffrey Binnie counts thirty completed; Geoffrey Binnie, "The Evolution of British Dams," in Dams, ed. Donald C. Jackson (Aldershot, 1998), 94.

${ }^{25}$ Russell, "John Frederic La Trobe-Bateman," 133. Chadwick, of course, was not solely responsible for Bateman's conversion to a professional water supply engineer, but Bateman's biographer attributes much influence to the activity of the Health of Towns Association and the 1844-45 Health of Towns Commission; see ibid., 105. Prior to 1844, Bateman had promoted only one project devoted solely to drinking water for Brighton in 1842; it was completed in 1849; see ibid., 124.

${ }^{26}$ Russell, "John Frederic La Trobe-Bateman,” 176, 182, 211.

${ }^{27}$ Irene Maver, Glasgow (Edinburgh, 2000), 91.

${ }^{28}$ Gravitation schemes quickly became renowned for their great cost, and some critics saw their designers as profligate. Russell, "John Frederic La Trobe-Bateman," 207. In Ceylon, Colonial Office officials recognized that the gravitation scheme was more expensive than alternatives, but they ultimately supported it nonetheless because their engineer represented it as the best. Minutes of R. Meade, "The Gravitation Scheme for Colombo Water Supply," 21 April 1877, The National Archives: Public Record Office (hereafter TNA: PRO) CO 54/510, 1877. 


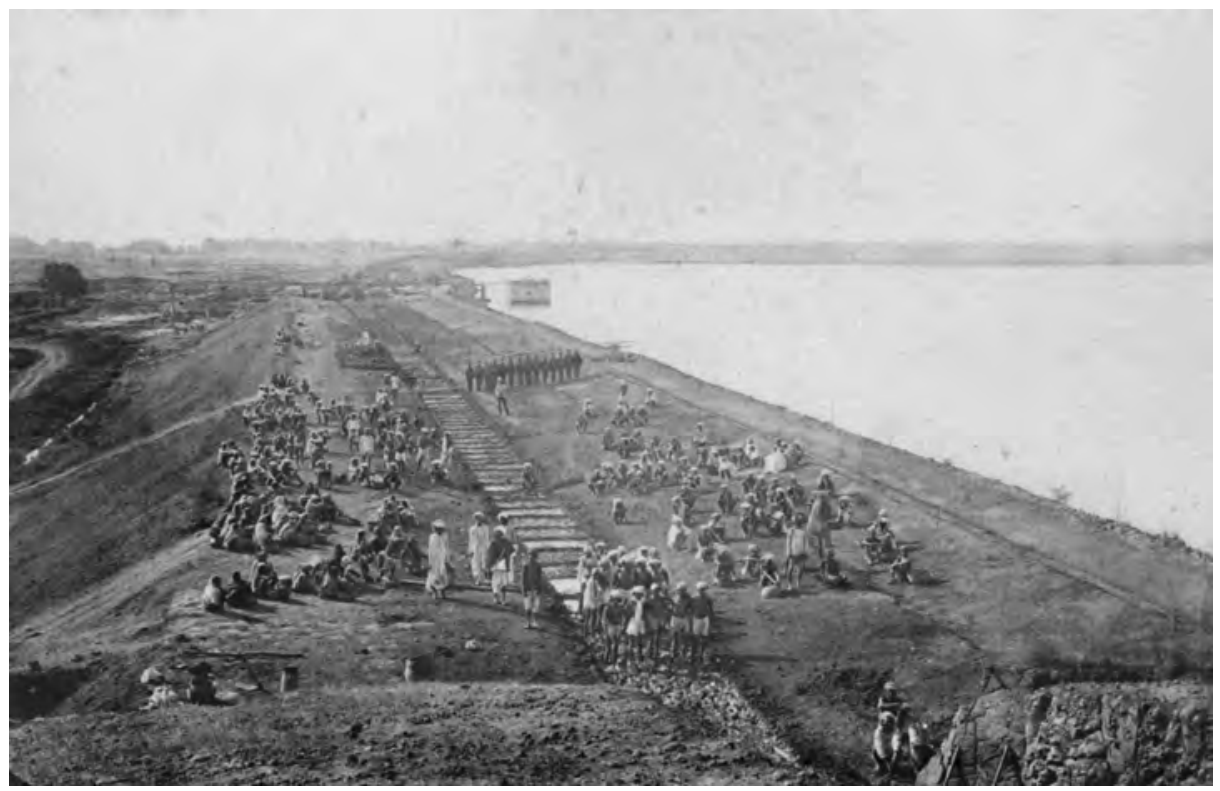

Figure 2-Alexander Binnie's Nagpur waterworks, 1870. Inmates from a nearby prison march in place to churn many layers of clay mixed with water into a single, uniform clay wall that will form the watertight core of the earthwork embankment (J. M. Morris, Description of the Nagpur [Ambajhari] Water-Works [Bombay, 1872]; courtesy of the Institution of Civil Engineers).

Conybeare, proposed a gravitation scheme in Bateman's style for Bombay in 1854. In promoting the scheme to colonial authorities, Conybeare emphasized that it was based on the "modern" water systems of Britain; he composed extensive reports describing how he had been guided by the experiences of British engineers in supplying water to cities such as Liverpool and Glasgow and assured his superiors that his design was "that usually employed in Great Britain." 29 In 1855, Conybeare traveled to Britain to arrange the manufacture of the scheme's great iron main, to tour the latest gravitation waterworks sites, and to meet with municipal water committees and their engineers in Liverpool, Manchester, Leicester, Bristol, and Glasgow. The Bombay government rushed the construction of his project, and it was completed in 1858 .

The gravitation scheme also spread to the empire because the students of the scheme's originators advanced it there. One of John Bateman's former students, Alexander Binnie, proposed a gravitation scheme for the central Indian city of Nagpur (see fig. 2). ${ }^{30} \mathrm{He}$ dammed a wide valley with a huge earthwork embankment and passed the water from the new reservoir through a 2.5 -mile iron pipeline

\footnotetext{
${ }^{29}$ Henry Conybeare, On the Supply of Water to Bombay (Bombay, 1854), 54-55, 68, and Second Report on the Supply of Water to Bombay (Bombay, 1855), 14.

${ }^{30}$ The chief public works commissioner for the city of eighty-four thousand sought Binnie out for his expertise and wrested him away from the Government of India's Public Works Department in 1870. See Central Provinces Public Works Department, Nagpur and Ambajerry Water Works (Nagpur, 1873), 3. For more on Binnie's Nagpur project in general, see also J. M. Morris, Description of the Nagpur (Ambajbari) Water-Works (Bombay, 1872).
} 

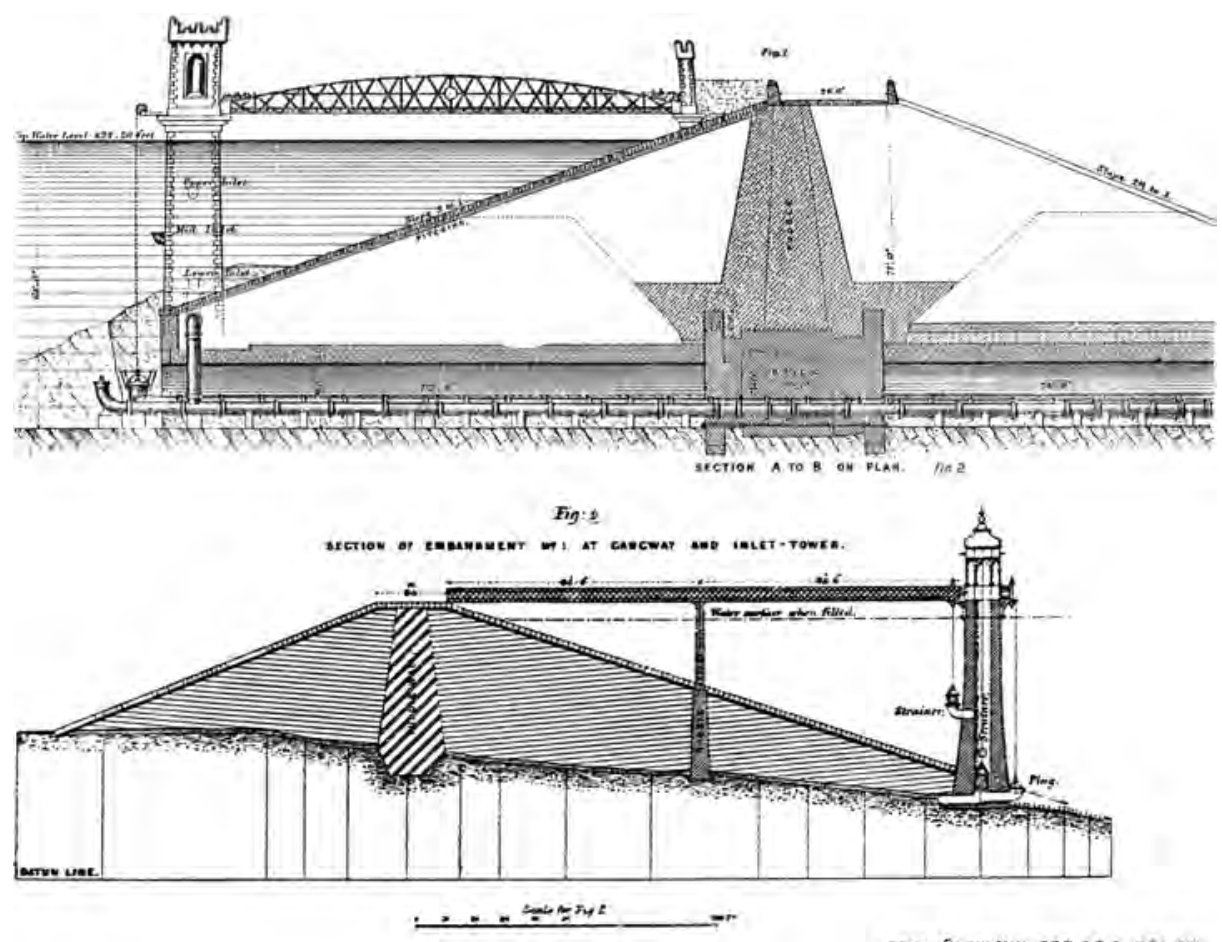

Figure 3-Top, valve tower and embankment of Vartry gravitation scheme, Dublin, 1860 (Minutes of Proceedings of the Institution of Civil Engineers [London, 1874], pl. 17; courtesy of the Institution of Civil Engineers). Bottom, valve tower and embankment of Vihar gravitation scheme, Bombay, 1858 (Minutes of Proceedings of the Institution of Civil Engineers [London, 1854], pl. 13; courtesy of the Institution of Civil Engineers).

to the city below. ${ }^{31}$ Binnie explained to his employers that he was working on the model of his teachers, writing, "For a full exposition of the principles on which I have acted . . . I invite careful study of . . . the valuable opinions expressed by Mr. Bateman and Mr. Hawkesley." ${ }^{\prime 2}$ Binnie completed his project in 1872.

The next year the Colonial Office hired Bateman himself to propose a system of water supply for Colombo, the main port of the Crown Colony of Ceylon (Sri Lanka). Bateman proposed a classic gravitation scheme for Colombo; his plan called for the construction of a massive dam, flooding an alpine valley, and a twentyeight-mile pipeline to the port below. The system, in sum, was identical to any number of waterworks (see fig. 3) that Bateman had designed in Britain, including

${ }^{31}$ Central Provinces Public Works Department, Nagpur and Ambajerry Water Works, 4.

${ }^{32}$ Alexander Binnie, Nagpur Water Works: Report to the Members of the Managing Committee, 30 September 1873, 11 and 13, Institution of Civil Engineers Archives, London, 1873BINCPW. Shortly after building his Nagpur gravitation scheme, Binnie returned to England to construct a gravitation scheme for Bradford. In 1889 Binnie became the first chief engineer of the London County Council and proposed a gravitation scheme for London that called for the importation of water over 150 miles from Wales-a scheme that London's local government intended to build but for which it could not secure authority from Parliament. 
his renowned Loch Katrine waterworks for Glasgow. Indeed, the main local newspaper, the Ceylon Observer, made the obvious comparison to Bateman's famous gravitation project, proudly calling the new lake "Ceylon's Loch Katrine" 33

Another of Britain's leading hydraulic engineers devised a plan to supply Singapore with water. In 1872, Parliament's chief engineering inspector, Robert Rawlinson, devised a plan to dam a stream and flood a valley in the hills above Singapore and deliver water from the reservoir through a five-mile pipeline to the city. ${ }^{34} \mathrm{He}$ also devised another classic gravitation scheme for Hong Kong ten years later. This plan called for another earthwork embankment of the standard profile in order to flood a valley five miles south of Victoria Harbor.

At about the same time, Japan's modernizing Meiji government asked Royal Engineer Henry Palmer to offer a waterworks scheme for the international treaty port of Yokohama. ${ }^{35} \mathrm{He}$ promised "to provide Yokohama with an ample water supply on Western principles." 36 He offered a gravitation scheme, damming a narrow alpine valley and piping water twenty-seven miles through an iron main to the city far below. This project was completed in 1887 . Over the next few years, Palmer was invited by the cities of Osaka, Hakodate, Kobe, and Tokyo to consult with them on water supply and sanitation works advising them, as he wrote in the Japan Weekly Mail, "to give immediate heed to their water supply . . . and to trust in the experience, not of Yokohama alone, but of the rest of the civilized world." ${ }^{37}$

\section{EXPORTING SOCIAL GOALS}

As in Britain, engineers and officials in the empire touted the technological superiority of the gravitation scheme model, but they also emphasized its social benefits. ${ }^{38}$ Henry Conybeare argued that his scheme for Bombay would benefit public health, economic productivity, and public morality. Mustering many pages of statistics and other evidence, he stated that the British registrar general's mortality returns for London and other cities showed that improved water supply and drainage systems reduced rates of mortality in Britain, and while he had no census or mortality data for Bombay, he argued that Bombay would receive the same benefits from new water systems, writing, "I think that such English data will be allowed to be perfectly applicable to the case." ${ }^{39}$ Conybeare was in part motivated by a desire to keep the working class of Bombay productive. The poor of Bombay, like the poor of the cities of England, could be spared an untimely death by water

\footnotetext{
${ }^{33}$ Ceylon Observer, 15 October 1888, reprinted in A Holiday Trip to Labugama: The Source of the Colombo Water Supply (Colombo, 1891), 85-86.

${ }^{34}$ Letter of J. McNair to the Colonial Office, 9 April 1878, 6-7, TNA: PRO CO 273/94, 1878, vol. 2.

${ }^{35}$ The government made its request in 1883. John Turner Tudsbery, "The Construction of the Yokohama Water-Works," in Minutes of Proceedings of the Institution of Civil Engineers, 18 February 1890 (London, 1890), 277-89.

${ }^{36}$ Hiro Higuchi, The Biography of Major-General H. S. Palmer, R.E., F.R.A.S. (Tokyo, 2002), 56.

${ }^{37}$ Ibid., 72.

${ }^{38}$ Meade, "Gravitation Scheme for Colombo Water Supply."

${ }^{39}$ Henry Conybeare, Report on the Sanitary State and Sanitary Requirements of Bombay (Bombay, 1852), 3 .
} 
reform, Conybeare wrote, and "for every death occasioned by preventable causes, there are, according to the best English medical authorities, at least fourteen cases of illness, more or less protracted, during which the patient is not only unproductive himself, but is a burden to the productive labor of others." 40

Conybeare also cited British municipal and sanitary authorities who argued that dirty or insufficient water led to moral disease among the working class. He quoted preeminent sanitarian Dr. Southwood Smith who proclaimed "the immoral influence of filth" and quoted the superintendent of police in Glasgow who argued that "much might be done to relieve the misery and repress the crime of [the] destitute population by compelling attention to personal cleanliness." ${ }^{41}$

In Hong Kong in 1881, Osbert Chadwick, son of arch sanitarian Edwin Chadwick, inspected the water supply and drainage provisions of that city. He himself was a waterworks engineer and consulted on water supply schemes in Britain and the colonies. He reported that "the dwellings of the Chinese working classes are inconvenient, filthy, and unwholesome. Accumulations of filth occur in and around them." ${ }^{22}$ Chadwick generously allowed that "it is unjust to condemn [the Chinese] as a hopelessly filthy race till they have been provided with reasonable means for cleanliness." ${ }^{43}$ Chadwick proposed a gravitation scheme that would allow authorities to compel the poor to accept laid-on water supplies and would make affordable water available to all parts of the city and all parts-even upper floors-of tenements. Only by requiring working-class townspeople-in Manchester or Hong Kong - to change their water use habits could authorities achieve their goals of safeguarding workers' individual physical and moral health and the productivity and safety of society at large.

\section{ENVIRONMENTAL AND SOCIAL CHANGE: ENVIRONMENTAL AND SOCIAL RESISTANCE}

As with so many of their economic and political policies, British environmental policies were imposed upon the colonies with little understanding of the situation on the ground. Officials exported this water supply scheme as if what worked in Britain should naturally work anywhere else, but foreign landscapes proved harder to dominate than British engineers expected. In Singapore, for example, engineers built tall earthwork embankments on the precise model prescribed by the system's London designer; twice they collapsed before construction was complete. The engineer had taken soil samples and found what he had expected, but he had not dug deep enough - a stratum of the subsoil deep beneath the embankments was something like quicksand. The resident engineer in Singapore subsequently reported that "the soil did not at all answer the original expectations, it was treach-

\footnotetext{
${ }^{40}$ Ibid., 22.

${ }^{41}$ Ibid. A member of Ceylon's legislative council argued for water reform for Colombo on the basis of a report on the sanitary condition of Glasgow made by Dr. Lyon Playfair, an eminent sanitarian. Councilor Dunlap is quoted in the Ceylon Observer, 5 November 1874, 566.

${ }^{42}$ Osbert Chadwick, Report on the Sanitary Condition of Hong Kong (London, 1882), 41.

${ }^{43}$ Ibid.
} 
erous and deceptive." ${ }^{44}$ The project ran 45 percent over budget and several years beyond the intended date of completion. ${ }^{45}$ Engineers in Colombo, Sri Lanka, also struggled with the unanticipated behavior of the local environment. There, the settling reservoir on the edge of the city collapsed twice as it was being filled. A local observer wrote in a guidebook to the city that "the city reservoir . . . has been a fiasco, cracking again and again." ${ }^{46}$ Temperatures far higher than any the London-based engineer had ever experienced caused the masonry and concrete to expand and contract to a point where it cracked. ${ }^{47}$ In Yokohama, an earthquake wreaked havoc on the gravitation waterworks. The earthquake of 1923 proved that while it was safe to build water conduits in Britain out of brick, it was inadvisable to do so in Yokohama where the ground was not nearly so steady. The brick water conduits collapsed, leaving the burning city below without water for two weeks. ${ }^{48}$

In Bombay, as in Singapore, the soil did not live up to engineers' expectations. In Britain, civil engineers buried pipes to keep them from freezing in cold months; in Bombay, they would have been far better off leaving them out of the corrosive soil. The great iron main that delivered the water from the reservoir to the city below, buried in soil that engineers did not know was saline, began to rust severely within a decade or two. A thick layer of rust coated great lengths of the pipe, and in some areas the pipe corroded so badly that it could be cut with a penknife. ${ }^{49}$ The main began to burst frequently, leaving the city without water while repairs were undertaken. ${ }^{50}$ Within Bombay's reservoir another problem emerged that engineers had never experienced in Britain; the intense tropical sun promoted the rapid growth of plant life at all depths of the still, warm water, and it became suffused with algae. Engineers later lamented that there was no mechanism for emptying the reservoir periodically to clean out the plant matter, but, of course, the design was based on the model from Britain-where there certainly was no tropical sun and where algae did not engulf reservoirs. ${ }^{51}$ The algae did not impair the operation of the Bombay gravitation scheme, but the works did become renowned for the poor quality of their water. ${ }^{52}$

In addition to forcing change on uncooperative environments, these projects had a direct influence on local societies. The water schemes involved large-scale environmental change, they all involved permanently transforming valleys into lakes, and many of them resulted in the displacement of indigenous people. At Bombay, for example, the two-square-mile lake engineers created drowned the village of Vihar. ${ }^{53}$ In each instance, a sort of "wilderness preserve" was also de-

${ }^{44}$ Letter of J. McNair to the Colonial Office, 9 April 1878, 9-10, TNA: PRO CO 273/94, 1878, vol. 2.

${ }^{45}$ Colonial Office Dispatch, 1 June 1878, 1-4, TNA: PRO CO 273/94, 1878, vol. 2.

${ }^{46}$ John Ferguson, Ceylon in the Jubilee Year (Colombo, 1887), 118.

${ }^{47}$ A. W. Burnett, Report on the Colombo Waterworks (n.p., 1890), 76.

${ }^{48}$ Katsumi Horie, The Earthquake Disaster and Reconstruction of Water Supply Works in Yokohama (Yokohama, 1930), 10, 12, 39.

${ }^{49}$ Hector Tulloch, The Water Supply of Bombay: Being a Report to the Bench of Justices of that City (London, 1872), 23.

${ }^{50}$ Ibid.

${ }^{51}$ Ibid., 25.

${ }^{52}$ S. Tomlinson, Bombay Municipality Water Works, Pawai Project (Bombay, 1889), 1-2.

${ }^{53}$ Tulloch, Water Supply of Bombay, 19, pl. 3. 
marcated around the new reservoirs to keep runoff from human inhabitation and agricultural activity from entering them. A village in proximity to Nagpur's new reservoir was removed in the early 1890s, and an auxiliary reservoir built in Bombay's hinterland displaced farmers for the same reason. ${ }^{54}$ Even as the governor was touting the water scheme's advantages for the "poor classes in the town," Singapore officials uprooted native farmers and swineherds from the catchment area of its new reservoir. ${ }^{55}$ Colonial officials in Ceylon removed local farmers from proximity to Colombo's new reservoir, and Hong Kong authorities displaced native inhabitants who lived near its new reservoir. ${ }^{56}$ In India, the water schemes interfered with religious customs, as British authorities restricted bathing and cremation rituals in proximity to new reservoirs. ${ }^{57}$ The creation of a new waterworks at a holy site on the banks of the River Ganges in Benares (today Varanasi) even led to a riot in that city in $1892 .{ }^{58}$

Before the gravitation schemes delivered water to all parts of these colonial cities, townspeople drew their water from wells and cisterns dotted throughout the cities. But a number of municipal governments ordered these long-standing water sources closed once the new water supplies became available. Medical officers were eager to close wells in the cities of Britain, once municipal water supplies became available, and public health committees from Hong Kong to Colombo to Bombay followed suit. ${ }^{59}$ Singapore authorities, for example, closed down many public and private wells in the decade after inaugurating its gravitation scheme. ${ }^{60}$ In Bombay, water from the new waterworks replaced many cisterns and wells that were closed because authorities believed that they were becoming infused with pollution and because they provided breeding grounds for mosquitoes. ${ }^{61}$ The editors of the biweekly Native Opinion complained that "the filling up of tanks and wells has been a hobby" of the presidencies "to the detriment of the people"

\footnotetext{
${ }^{54}$ Annual Report of the Sanitary Commissioner with the Government of India, 1892 (Calcutta, 1894), 194; Tomlinson, Bombay Municipality Water Works, 5.

${ }^{55}$ Letter of Sir W. Robinson to the Colonial Office, 1 June 1878, 20-22, TNA: PRO CO 273/94, 1878 , vol. 2. For the removal of farmers, see also Singapore Municipality, Singapore Municipality Waterworks: Opening of New Works (Glasgow, 1912), 14.

${ }^{56}$ For Colombo, see Holiday Trip to Labugama, 14; for Hong Kong, see Ho Pui Yin, Water for a Barren Rock: 150 Years of Water Supply in Hong Kong (Hong Kong, 2001), 30.

${ }^{57}$ Harrison, Public Health in British India, 173.

${ }^{58}$ Hugh Tinker, The Foundations of Local Self-Government in India, Pakistan, and Burma (London, 1954), 58. This story repeated in Harrison, Public Health in British India, 174.

${ }^{59}$ For a few examples of health reformers' attitudes toward well water supplies in Britain, see Malcolm Elliot, Victorian Leicester (London, 1979), 126; Thomas Dale, On the Supply of Water to the Lancashire and Yorkshire Towns from the Lake Districts of Cumberland and Westmoreland (London, 1866), 4-5; John Burnet, History of the Water Supply of Glasgow (Glasgow, 1869), 2. On colonial sanitarians' instincts for suspecting native wells, see, for just a few examples among many, Proceedings of Third All-India Sanitary Conference, Held in Lucknow, January 1914 (London, 1914), 188-89; Chadwick, Sanitary Condition of Hong Kong, 17.

${ }^{60}$ Public Utilities Board, Yesterday and Today: The Story of Public Electricity, Water, and Gas Supplies in Singapore (Singapore, 1985), 9. For the Health Department closing wells in Singapore, see also Arnold Wright, Twentieth Century Impressions of British Malaya: Its History, People, Commerce, Industries, and Resources (London, 1908), 606.

${ }^{61}$ Samuel Townsend Sheppard, Bombay (Bombay, 1932), 108-9; Mariam Dossal, Imperial Designs and Indian Realities: The Planning of Bombay City, 1845-1875 (Bombay, 1991), 117.
} 
because it reduced available water sources. ${ }^{62}$ In Bombay, the sealing of the wells resulted, according to the municipal secretary, in "vehement" protests motivated by religious beliefs. "The aggrieved parties," he wrote, "gave chapter and verse to show that their scriptures enjoined the use of well water, and well water only, in connection with divers ceremonies." $"{ }^{33}$ The Hindu community complained that their religion demanded the use of well water in a number of ceremonies, while the Zoroastrian community argued that the wells had supernatural powers or that spirits inhabited them. ${ }^{64}$ But the city's malarial officer was unmoved; he continued to seal wells—and quickly became reviled among the devout. ${ }^{65}$

By closing existing wells and tanks, colonial authorities were acting directly to change townspeople's behavior. They were keeping Indian subjects from using traditional water sources assumed to be dangerous, with the expectation that subjects would have to use new official water supplies instead. The substitution of new colonial water sources for traditional sources was not all pervasive and did not happen overnight; older forms and new ones coexisted for a period, but as wells and tanks were covered, new waterworks slowly became the only source of the prime necessity for native city dwellers' lives. The water systems, it follows, made those subjects more dependent on colonial authorities; they centralized control of the most critical element in the hands of the British, when the availability of water had formerly been decentralized.

But much of the influence of the new water system was indirect. The gravitation scheme helped slowly usher in new standards of normalcy or, in the words of Scott, new "forms of life," among city dwellers. ${ }^{66}$ Pipelines, taps, and standpipes, along with the campaigns of sanitarians, what one Indian commentator called deridingly, "the rules of sanitation," invited new routines and a new scale of water use. $^{67}$ The new water technology made heavy water use as a moral endeavor possible; that is, it took an abstract, universal principle held by the British and altered the reality of the city so that it could possibly be realized. The power of the modern state grew through possibility; as Tal Asad explains, new possibilities were constructed through new methods and technologies, and the gravitation scheme was such a technology, contributing in a piecemeal way to an urban fabric that reflected the ideas that access to urban utilities should be easy and widespread, that former limitations on health, growth, and free circulation imposed by nature should be overcome, and that local government has an ameliorative rather than just coercive role ${ }^{68}$ The new water supplies were the first necessity and core of the modernizing city, contributing to the evolution of a new kind of setting in which a "civilized,"

\footnotetext{
${ }^{62}$ Native Opinion, 9 October 1892, reprinted in Report on Native Newspapers Published in the Bombay Presidency and Berar, 1892 (Bombay, 1893), sec. 42, 16-17.

${ }^{63}$ Rustom Pestonji Masani, Folklore of Wells: Being a Study of Water-Worship in East and West (Bombay, 1918), 4-5.

${ }^{64}$ Ibid., 4-9, 20.

${ }^{65}$ Ibid., 11. Masani writes that, even after they had been filled in, townspeople continued to leave sacrifices above two particularly important wells (ibid., 23-24).

${ }^{66}$ Scott, "Colonial Governmentality," 193.

${ }^{67}$ The writer rejected the guidelines of British sanitarians as actually detrimental to public health (Hindusthán, 18 September 1892, reprinted in Report on Native Newspapers Published in the Bombay Presidency and Berar, 1892, sec. 39, 19).

${ }^{68}$ Tal Asad, "Conscripts of Western Civilization," in Dialectical Anthropology: Essays in Honor of Stanley Diamond, vol. 1, ed. Christine Gailey (Gainesville, FL, 1992), 337.
} 
"improved," or modern life could be lived-until at some indeterminate point only a modern life could be lived.

\section{PROTESTING THE GRAVITATION SCHEME}

Some native townspeople opposed gravitation systems or called for alternatives to the monumental schemes. Indigenous townspeople in Bombay, for example, opposed the creation of its gravitation scheme in late 1853. After Henry Conybeare and his surveyors began making preliminary maps of the Vihar Valley for their reservoir, the townspeople became alarmed at the extravagance of the project that was about to be foisted upon them. ${ }^{69}$ Jamsetjee Jejeebhoy, a leading native patrician, informed the governor of Bombay that the city's native majority was unconvinced of the project's necessity and resented being taxed to pay for a project over which they had no control. ${ }^{70}$ "The project of bringing water from Vehar does not find favor with the community in general," he wrote in $1854 .{ }^{71} \mathrm{He}$ added that "many persons . . . do not think that it should rest with any Engineer or Architect, however high his repute or abilities, to have the devising and execution of the plans, an almost unlimited power of expending the public money, subject only to the general control of Government, and without any control whatever on the part of those who have to pay for the works." ${ }^{72}$ Many townspeople, wrote Jejeebhoy, believed that the existing scattering of local water sources throughout the city should be augmented by new wells, instead of supplying the town through a single source. ${ }^{73}$ The local townspeople's protests had no effect; the Vihar scheme was inaugurated four years later.

From the early 1850s, the Bombay presidency envisaged Karachi as a future gateway to western India, but it worried that an inadequate water supply would impede the port town's progress. The government's commissioner in charge of Karachi, Sir Bartle Frere, ordered Karachi's wells examined, and the vast majority were judged unwholesome. ${ }^{74}$ Frere decided on a scheme for piping water from the Malir River ten miles northeast of the city in 1859. But the plan met with scorn at a public meeting of leading indigenous townspeople, including merchants, native magistrates, and representatives from each of the religious communities in the town. "The people," one British observer grumbled years later, "went to the extreme of offering general opposition to any scheme for satisfying their wants." 76 This complaint was echoed numerous times in myriad instances of scientific or technological imposition and reflected a conception of Asians as innately averse to change, no matter how patently beneficial that change might be in British

\footnotetext{
${ }^{69}$ Letter of Henry Conybeare to Lord Elphinstone describing surveying expeditions, 4 November 1853, India Office Records MSS Eur F87/154, British Library.

${ }^{70}$ Jamsetjee Jejeebhoy to Lord Elphinstone, 26 October 1854, India Office Records MSS Eur F87/ 163, British Library, 5, 8, 10.

${ }^{71}$ Ibid., 1.

${ }^{72}$ Ibid., 10.

${ }^{73}$ Ibid., 4.

${ }^{74}$ A. W. Hughes, A Gazeteer of the Province of Sind, 2nd ed. (London, 1876), 378.

${ }^{75}$ Behram Sohrab H. J. Rustomji, Karachi, 1839-1947 (Karachi, 1952), 125.

${ }^{76}$ Alexander F. Baillie, Kurrachee: Past, Present, and Future (Calcutta, 1890), 107.
} 
eyes. ${ }^{77}$ But in the townspeople's eyes, they had no need of such a scheme; they protested that many households had a well located in their garden, and townspeople who did not have their own well could draw water from the many wells that lined the bed of the river that passed near to the town. ${ }^{78}$ The project was shelved for many years, not because of the protests of the towns' inhabitants but because the Bombay government did not approve of their local administrators' plan to finance the project through transit duties at Karachi's port. After the British finally did complete a Malir River scheme in 1883, British observers congratulated themselves for improving the lot of the poor townspeople and for contributing to their "personal cleanliness." "79

In 1874, native residents of Colombo held a public meeting near the town hall, angry that they would be taxed to pay for a grand scheme imposed on them by the island's colonial authorities. They were soon chanting, "Vatura epaa [no waterworks]!" members to meet with the colony's governor, complaining about the water proposal's extravagance and arguing that if any project were undertaken, it should include native laborers and engineering skill. ${ }^{81}$ The Colonial Office, however, imposed its own plan and engineer upon Colombo.

In Hong Kong, Chinese citizens worried that colonial officials' plans to manage water would mean an increase in official intrusion. Osbert Chadwick wrote that local residents "raised objections" based on "a dread of tyrannical interference by public officials, of 'squeeze,' in short." ${ }^{82}$ Besides equating water control with social control, citizens simply resented new taxes on water projects that they had not asked for. ${ }^{83}$ Chadwick was not concerned about townspeople's objections; he ended his report on Hong Kong by writing that "the Chinese, it appears, are a most docile people, and are accustomed for countless generations to implicit submission to authority. Once let them see that Government is in earnest about sanitation and that, whilst giving facilities, ... there is a firm determination to enforce cleanliness [and there will be little resistance]. ${ }^{84}$ Engineers discussing the completion of Hong Kong's and Yokohama's gravitation schemes a few years later remarked on the hostility and "prejudice" of the "Oriental" toward the introduction of water systems. They assured themselves, however, that once "the pioneers of the profession ... strenuously worked against initial difficulties and

\footnotetext{
${ }^{77}$ See numerous expressions of this attitude among imperial officials and observers in Arnold, Colonizing the Body, 238 and elsewhere.

${ }^{78}$ Rustomji, Karachi, 125.

${ }^{79}$ This project was designed by municipal engineer James Strachan. It was not a classic gravitation scheme in that it did not include flooding a valley or raising a lake behind an embankment. Instead, the Karachi scheme called for the excavation of two 45,000-cubic-foot wells or tanks. The water was imported from these tanks under gravity through a single pipeline over sixteen miles. The water was stored in a distribution reservoir above the town and reached Karachi under sufficient pressure to reach the upper floors of houses. Baillie, Kurrachee, 110-12.

${ }^{80}$ Ceylon Observer, 24 October 1874, 540; Ceylon Observer, 28 October 1874, 551.

${ }^{81}$ Ceylon Observer, 22 December 1874, 651.

${ }^{82}$ Chadwick, Sanitary Condition of Hong Kong, 2.

${ }^{83}$ Ibid.

${ }^{84}$ Ibid., 42.
} 
prejudices," colonial townspeople would learn to "enjoy the benefits of the European system of water distribution." $\$ 5$

\section{CONCLUSION}

Royal Engineer Alexander de Courcy Scott spoke of the benefits of the "European system of water distribution" at the same time that he spoke of the "Oriental's" inborn prejudice against innovation; his zealous confidence in the benefits of British hydraulic systems was only slightly less naive than his portrayal of human character in Asia. Gravitation projects probably did save human lives in Asia by safeguarding drinking water from infection with cholera and other diseases. (Their benefit has never been measured, however; no one has shown a correlation between increasing urban populations and the waterworks of various sorts present in the majority of large cities by around 1914. ${ }^{86}$ De Courcy Scott and other engineers' motivations may have been partly, even largely, to benefit the non-European city dwellers of cramped Hong Kong and Colombo, but the deeper effect of these projects was to modify native people's behavior, to guide and, as traditional water sources disappeared, to indirectly enforce behavior that the colonial state defined as "civilized" or modern.

This study hardly represents the first discovery of the moral contradictions inherent in the improving projects of the British in the empire. Historians have shown how irrigation projects promoted as the key to economic regeneration in the countryside in fact led to environmental tragedy for Indian farmers. ${ }^{87}$ Railroads, in addition to improving economic production and circulation, were ostensibly to literally and figuratively eliminate distance between castes and communities by mingling Indians of all castes in only two classes of service, but in fact rail transport raised new barriers by catering to Europeans in first class and resigning most Indians to poor conditions in second-class compartments and squalid station facilities. Projects for transportation, communication, and productivity were always framed as "essential for the advancement of the moral and material prosperity of the people," in the words of Manu Goswami, but as she and others show, the end of such projects was to benefit the colonial state and ultimately to solidify it. ${ }^{88}$ The case of the gravitation scheme adds another chapter to the history of the opposition between the rhetoric of improvement and the reality of power; because water systems have been perceived as self-evidently good, the power factor and social consequences of the projects have been overlooked. Indeed, whether in Britain or Asia, the state's demands for acceptance of "official" water supplies became naturalized. That demand is perceived now as the legitimate, beneficial activity of

\footnotetext{
85 "Discussion on Water-Works in China and Japan," in Minutes of Proceedings of the Institution of Civil Engineers, 18 February 1890, 100, 291-92.

${ }^{86}$ Tinker, Foundations of Local Self-Government, 290-91.

${ }^{87}$ See Whitcombe, Agrarian Conditions; John Mackenzie, "Empire and the Ecological Apocalypse: The Historiography of the Imperial Environment," in Ecology and Empire: Environmental History of Settler Societies, ed. Tom Griffiths and Libby Robin (Seattle, 1997), 218-19.

${ }^{88}$ Manu Goswami, Producing India: From Colonial Economy to National Space (Chicago, 2004), esp. chaps. 2 and 3.
} 
the modern state. Understood as common sense, this activity has only recently come under scrutiny.

Historians of science, technology, and empire have focused on projects for transportation, communication, and productivity, at the expense of water supply projects. A blind spot formed by two historiographical conventions has obscured such projects from view. The first holds that the British Empire in Asia and India in particular did not undertake projects important to the city because the city did not figure into its most important goal of enhancing the productivity of the hinterland landscape in order to increase exports and tax revenue. But the case of the gravitation scheme demonstrates an intense interest in the development of the imperial city, though it may have been quite narrow. The second convention, as explained by David Arnold and Mark Harrison, holds that local government, which undertook water supply projects in Britain, was vastly weaker in the empire, even consciously undermined by colonial authorities, and could not take dramatic steps toward public health. ${ }^{89}$ In the case of the gravitation scheme, action was taken by central imperial authorities in London or regional authorities in the empireusually not municipal bodies - so the general rule of local government impotency would not apply in the colonies. Mariam Dossal's work on Bombay challenges both of these conventions, and the case of the gravitation scheme builds on her important work..$^{90}$

This story also begins to address a lack of urban considerations in the colonial environmental history literature. That body of work has chiefly focused on how human land use strategies and certain plant and animal species aided in colonization. ${ }^{91}$ It has also examined the role of colonial botanical and conservation practices, especially imperial forestry, in transforming environments and societies in both the empire and imperial center. ${ }^{92}$ And, again, historians devoted much attention to irrigation schemes and their effects on peasant communities. ${ }^{93}$ An urban focus, and the case of the gravitation scheme in particular, links the city to the countryside and shows that the imperatives of the city drove environmental change in sometimes distant landscapes. ${ }^{94}$ The gravitation scheme certainly revolutionized local hydraulic cycles to as great an extent as many irrigation projects. It also shows that, by being dislodged from watersheds-cum-wilderness preserves, peasants were at the mercy of the city's environmental demands; at the same time, this case shows that the city dweller, the water consumer, was the ultimate object of the environmental projects of the colonial state-and not just the peasant as the existing literature implies. And while those large projects clearly influenced the indigenous agriculturalist, the case of the gravitation scheme reveals ways in

${ }^{89}$ Arnold, Colonizing the Body, 274-80; Harrison, Public Health in British India, 170-83.

${ }^{90}$ Dossal, Imperial Designs.

${ }^{91}$ The foundational works in this genre are Alfred Crosby, The Columbian Exchange: Biological and Cultural Consequences of 1492 (1972; repr., Westport, CT, 1990), and Ecological Imperialism: The Biological Expansion of Europe, 900-1900 (Cambridge, 1986). For another important example among many, see Elinor G. K. Melville, A Plague of Sheep: Environmental Consequences of the Conquest of Mexico (Cambridge, 1994).

92 The most important work in this genre is Richard Grove, Green Imperialism: Colonial Expansion, Tropical Island Edens, and the Origins of Environmentalism, 1600-1800 (Cambridge, 1995).

${ }^{93}$ See D'Souza's survey, "Water in British India."

${ }^{94}$ William Cronon's Nature's Metropolis is the critical exemplar of this kind of environmental history in the American context; Nature's Metropolis: Chicago and the Great West (New York, 1991). 
which environmental schemes influenced city dwellers in less obvious manners by changing patterns of water use.

Finally, the significance of the gravitation scheme stems from the fact that, unlike the scientific forestry programs and irrigation projects undertaken in India and elsewhere, this project was undertaken simultaneously in Britain. A strategy for transforming urban life, even modernizing society and consolidating the state, as Patrick Joyce and others explain, was replicated in Britain and the empire-and often by the very same individuals and on the same grounds of sanitary and moral theory. ${ }^{95}$ At home and abroad, rulers and reformers identified the same practical problems, the unhygienic habits of the working class or native city dweller, and the same abstract predicament, the moral degeneration of townspeople living among "filth," and applied the same environmental solutions. While the social and political contexts were different, the strategy and consequences were the same; in both places, British authorities saw reconfiguring the environment as a powerful tool for reforming society, and in both places the ultimate effect of the water system was to consolidate the authority of the modern state. Thus, Bombay and Manchester were "colonized" in the same way.

${ }^{95}$ In addition to Joyce, see Chris Otter, "Making Liberalism Durable: Vision and Civility in the Late Victorian City," Social History 27, no. 1 (January 2002): 1-15. 